Maria Skoczek

\title{
THE 25 YEARS OF THE FACULTY OF GEOGRAPHY AND REGIONAL STUDIES OF THE WARSAW UNIVERSITY (1977-2002)
}

The Faculty of Geography and Regional Studies of the University of Warsaw was established on September $1^{\text {st }}, 1977$, through the merger of the Institute of Geography (a self-standing organisational unit of the University, having the rights of a faculty), and the Institute of African Studies (previously a part of the Faculty of Modern Languages of the University). Since the middle of the 1990s the organisational structure of the Faculty has not been undergoing changes. Thus, in 2002 the Faculty was composed of three institutes: the Institute of Physico-geographical Sciences, with the Departments of Geoecology, Geomorphology, Hydrology, Climatology, and the Laboratory of Sedimentology; the Institute of Social, Economic and Regional Geography, with the Departments of Socio-economic Geography, Regional Geography, Didactics of Geography and Tourism; the Institute of Developing Countries, with the Departments of Regional Studies on Africa and Asia, Regional Studies on Latin America, Economic Development, Political, Social and Legal Studies, as well as four independent units, which are subordinated directly to the Deans, namely the Chair of Cartography, the Department of the Remote Sensing of Environment, the Laboratory of Computer Education, and the Masovian Geographical Laboratory (with the field station in Murzynowo, see Fig. 1).

The Faculty employs approximately 160 persons, of whom close to 100 are university teachers. The development of the teaching staff is illustrated below by the numbers of doctoral (Ph.D.) and habilitation (D.Sc.) dissertations defended before the Council of the Faculty of Geography and Regional Studies in the years 1977-2002 (until February $1^{\text {st }}, 2002$ ):

\begin{tabular}{|l|c|c|c|c|c|}
\cline { 2 - 6 } \multicolumn{1}{c|}{} & Totals & $\begin{array}{c}\text { Staff } \\
\text { and doctoral } \\
\text { students } \\
\text { of the Faculty }\end{array}$ & $\begin{array}{c}\text { Staff } \\
\text { of other } \\
\text { universities }\end{array}$ & $\begin{array}{c}\text { Persons } \\
\text { employed } \\
\text { in other } \\
\text { institutions }\end{array}$ & Foreigners \\
\hline $\begin{array}{l}\text { Doctorates } \\
\text { (Ph.D.) }\end{array}$ & 112 & 58 & 21 & 8 & 23 \\
\hline $\begin{array}{l}\text { Habilitations } \\
\text { (D.Sc.) }\end{array}$ & 37 & 22 & 8 & 7 & \\
\hline
\end{tabular}


The research conducted at the Faculty deals with the most important questions constituting the subject of interest of modern geography. In comparison with the other Polish university centres, which include the units running the studies in geography, the research carried out at the University of Warsaw is characterised by the broader treatment of the following domains:

- landscape ecology;

- modelling of hydrological processes;

- modern morphodynamic processes in various types of natural environments (in particular, the desert and periglacial environments);

- history of geographical thought with respect to human geography;

- man-environment relations in various areas of the world;

- comparative studies of the factors of development in various areas of the world, especially in Latin America, Africa, and Asia;

- methodology and methods of thematic cartography;

- application of remote sensing in the study of anthropogenic changes in the natural environment.

Some of the research programs are being carried out in collaboration with foreign partners. This concerns, first of all, the studies of the contemporary changes in the natural environment, conducted in the framework of international programmes, such as the Global Change or the International Hydrological Programme of UNESCO, as well as collaboration with the university centres in Egypt, Italy, Portugal, and the study of the contemporary transformations of socio-economic structures of towns and urban areas, carried out in co-operation with the universities in France, Czech Republic, Mexico, Peru, and Turkey. Special position has a project "URBS PANDENS" (Urban Sprawl: European Patterns, Environmental Degradation and Sustainability) which is run by our Faculty, in the framework of the Vth European Community Programme.

During the last few years changes took place in the organisation of teaching of graduate and doctoral students. And thus:

- a two-stage teaching cycle of education was introduced at the intramural and evening courses, namely the three-year licentiate study, followed by the two-year M.Sc. study, with specialisation directions of physical geography, economic geography, regional geography, and cartography;

- in the academic year 1999/2000 the M.Sc. study was introduced within the specialisation in physical geography, oriented at environmental protection, and within the specialisation of economic geography, oriented at the geography of tourism; they are both carried out as extramural studies.

There are currently altogether some 600 intramural students, some 200 students of the evening courses, and around 120 persons taking the supplementary M.Sc. courses. More than 2200 persons received the M.Sc. diplomas of the geographical studies in the period 1977-2002.

The analysis of the further fate of the persons having graduated from the Faculty showed that those who lived at the instant of graduation within the agglomeration of Warsaw did not have difficulties in finding of jobs. Half of 


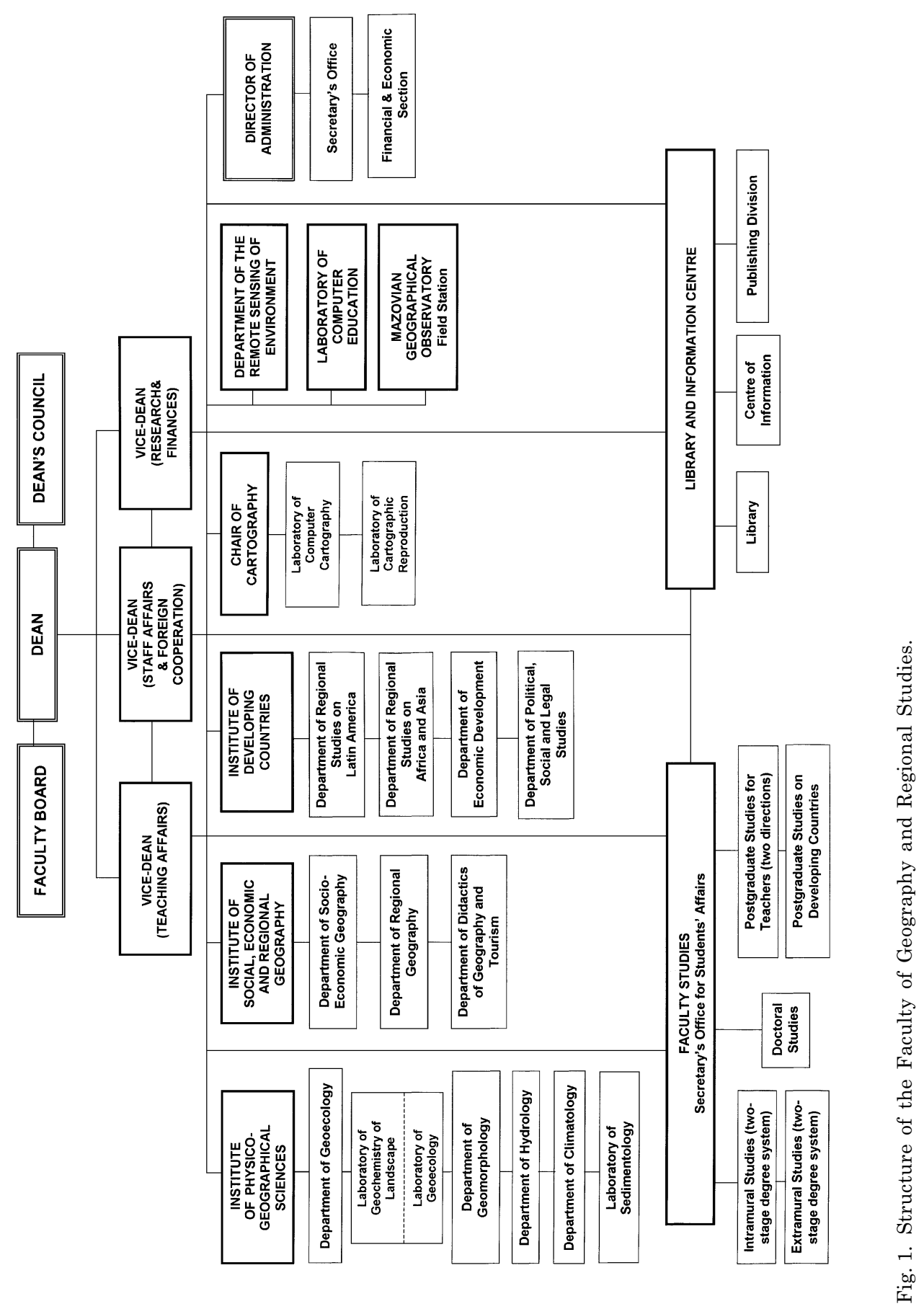


them worked in the private sector. The largest shares found employment in education (17\%) and research (13\%), as well as in other services (counselling $-16 \%$, trade $-14 \%$, finance $-11 \%$, media and administration). Close to $1 / 3$ concluded that a geographer was competitive on the labour market owing to the comprehensiveness of education and the capacity of flexible adaptation to the requirements of the employer and acquisition of new skills. Half of the graduates declared gaining of satisfactory salaries (Lisowski, 1999).

The Faculty of Geography and Regional Studies of the University of Warsaw conducts also the post-graduate studies. The longest record of functioning belongs to the four-semester Post-Graduate Study of the Developing Countries, being a continuation of the African Study, established at the University of Warsaw in 1962. This particular course was taken in the period 19772001 by 950 persons, with total enrolment in the academic year 2001/2002 being equal 70. Two post-graduate courses for teachers were established in the 1990s, namely the four-semester Study for the Teachers of Geography (terminated by approximately 500 persons in the years 1996-2001, the number of students in the academic year 2001/2002 being equal roughly 180), and the three-semester Study of Knowledge of Nature (terminated by 130 persons in the years 2000-2001, with 130 persons attending in the academic year 2001/2002).

Since the academic year 1994/1995 the four-year doctoral studies have been functioning, having as their main objective education of the future staff of the Faculty. There were 27 doctoral students in the academic year 2001/ 2002. Of the nine persons having obtained doctoral degrees at the studies, six were employed at the Faculty as the adjoint professors.

One of the more important forms of presentation of the results of the research activity at the Faculty is organisation of the seminars and scientific conferences, whose materials are published in the Faculty's publication series. During the last couple of years the consecutive meetings belonging to the cycles of international seminars, have been run, these cycles being, in particular, the following ones:

- the Polish-Mexican geographical symposia, carried out since 1977 in collaboration with the Autonomous University of the State of Mexico;

- the Polish-Czech-Slovak geographical seminars, organised since 1963 jointly with the Charles University in Prague, and since 1997 also together with the Jan Komensky University in Bratislava;

- the Polish-Russian geographical seminar, organised since 1995 in collaboration with the Lomonosov Moscow State University;

- the seminars organised jointly with the International Association of Landscape Ecology (IALE).

An interesting initiative is constituted by the Conferences of Young Scientists, organised since 1998 by the Institute of Developing Countries, with participation of the doctoral students, the M.Sc. students, and the graduates, carrying out the studies concerning the contemporary socio-economic processes. 
The Faculty conducts the publication activity, which makes up an important form of popularisation of the results of research and of the educational achievements. Two publication series appear in the Polish language, Prace $i$ Studia Geograficzne (Studies in Geography), of which 30 volumes have been published in the years 1977-2002, and Afryka, Azja, Ameryka Eacinska (formerly Przeglad Informacji o Afryce), with 22 volumes published in the years 1977-2002. Three series are published in foreign languages: Miscellanea Geographica (10 volumes in the years 1984-2002), Africana Bulletin (24 volumes in the years 1977-2002), as well as Actas Latinoamericanas de Varsovia (with 25 volumes having appeared in the period 1984-2002). Another series published by the Faculty is - in Polish language - the Atlas of interdependence of meteorological and geographical parameters in Poland (15 volumes have been published in the years 1974-2002). Side by side with these serial publications, several dozen of research dissertations, a dozen or so lecture notes, as well as information booklets on the studies and the Faculty have been published between 1977 and 2002 .

There is a very active Scientific Circle of the Students of Geography at the Faculty, whose tradition dates back to the 1920s. During the 1980s the initiative of this Circle led to the establishment of the European Association of Young Geographers (EGEA), as well as of PANGEA, associating the youngest graduates of the Faculty. PANGEA and the Circle publish their own quarterly Geozeta. An interesting aspect of activity of the scientific circles of students is constituted by the expeditions to many regions of the world. Reports from these expeditions are presented at the annual sessions of the Circle, and are also published in Geozeta.

\section{REFERENCES}

Lisowski, A., 1999, Zatrudnienie absolwentów geografii Uniwersytetu Warszawskiego w latach 90 [Employment of the graduates of geography of the University of Warsaw in the 1990s; in Polish], [in:] Geografia na przełomie wieków - jedność w różnorodności, A. Lisowski, ed., Wydział Geografii i Studiów Regionalnych Uniwersytetu Warszawskiego, Warszawa.

Mikulski, Z., ed., 1995, Dzieje studiów geograficznych w Uniwersytecie Warszawskim, 19181993 [The history of the geographical studies at the University of Warsaw 1918-1993; in Polish], Prace i Studia Geograficzne, vol. 16, Wydawnictwa Uniwersytetu Warszawskiego, Warszawa. 